\title{
A debreceni gazdaságfejlesztés zászlóshajói: a városban müködő ipari parkok jellegzetességei
}

\section{Flagships of economic development of Debrecen: characteristics of industrial parks in the city}

\author{
MOLNÁR ERNŐ, KOZMA GÁBOR
}

MOLNÁR Ernő: egyetemi adjunktus, Debreceni Egyetem, Természettudományi és Technológiai Kar, Földtudományi Intézet, Társadalomföldrajzi és Területfejlesztési Tanszék, 4032 Debrecen, Egyetem tér 1.; molnar.erno@science.unideb.hu; https:// orcid.org/0000-0001-8157-4222

KOZMA Gábor: egyetemi tanár, Debreceni Egyetem, Természettudományi és Technológiai Kar, Földtudományi Intézet, Társadalomföldrajzi és Területfejlesztési Tanszék, 4032 Debrecen, Egyetem tér 1.; kozma.gabor@science.unideb.hu; https://orcid.org/00000001-5242-3580

KULCSSZAVAK: ipari park; Debrecen; helyi gazdaságfejlesztés

ABSZTRAKT: Az ipari parkok az elmúlt időszakban fontos szerepet töltöttek be a magyar gazdaság fejlesztésében, a helyi önkormányzatok is kiemelt figyelmet fordítottak alkalmazásukra. A tanulmány célja, hogy bemutassa az ipari park címmel rendelkező objektumok sajátosságait és helyét Debrecen gazdasági életében. A vizsgálatok során felhasználtuk a város rendszerváltás után készített, gazdaságfejlesztéssel foglalkozó terveit és stratégiáit, saját adatgyűjtés keretében felmértük az ipari parkok jellegzetességeit és az ott múködő cégeket.

A kutatás eredményei közül kiemeljük, hogy az 1990-es évek elejétől kezdve az ipari parkok a helyi gazdaságfejlesztési stratégiák fontos elemei, a helyi gazdaság zászlóshajóivá váltak, kínálatuk folyamatosan bővül. Az ipari parkok eredetük, tulajdonosaik és müködési formáik alapján változatosságot mutatnak, gazdasági szerkezetükben a feldolgozóipar mellett a kereskedelem és a szállítás-raktározás szerepe is jelentős. Az ipari parkokban müködő cégek a város gazdaságának fontos bázisát alkotják (ez különösen igaz a nagyobb vállalatokra).

Ernő MOLNÁR: assistant professor, Department of Social Geography and Regional Development Planning, University of Debrecen, Egyetem tér 1., H-4032 Debrecen, Hungary; molnar.erno@science.unideb.hu; https://orcid.org/0000-0001-8157-4222

Gábor KOZMA: professor, Department of Social Geography and Regional Development Planning, University of Debrecen, Egyetem tér 1., H-4032 Debrecen, Hungary; kozma.gabor@science.unideb.hu; https://orcid.org/0000-0001-5242-3580

KEYWORDS: industrial park; Debrecen; local economic development

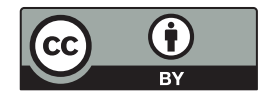


ABSTRACT: Industrial parks have played a very important role in the development of the Hungarian economy in recent decades. Thanks to the commitment of local authorities, their number has increased significantly. The study aims to identify the characteristics of industrial parks and their position in the local economy, in this case in the Hungarian city of Debrecen, Hungary.

Different types of information sources were used. On the basis of documents on local economic development after the change of the political system, the most important features of objects listed under "industrial parks" approved by the Hungarian state and the enterprises located there were examined. The data collected in this way were compared with official data from various databases.

The most important research results can be summarised as follows. The objects found have been an important component of local economic development strategies since the early 1990s. In most cases, the city authorities regarded them as flagships of the local economy and therefore aimed for a continuous further development of their investment. This includes the gradual expansion of dedicated zones, the development of the infrastructure required for the settlement of companies and, more recently, the improvement of their increasingly important accessibility.

Industrial parks vary widely in terms of origin, ownership and functioning. Both brownand green-field developments can be found in the city, although real growth potential (e.g. the expansion of its area) can only be seen in green-field zones. Among the owners/operators are both non-profit and for-profit companies, and in one industrial park, the companies owning sites locally are also the owners of the industrial park's operating company. The economic structure is characterised by wholesale and retail trade, transport and warehousing alongside manufacturing.

The companies operating in the industrial parks constitute an important basis for the local economy, in terms of both their number and the number of employees (this applies in particular to the larger companies). The recent location decisions by investors indicate that industrial parks will continue to play an important economic role in the future.

\section{Bevezetés}

Az ipari park a hazai gazdaság- és területfejlesztési politika fontos eszköze. Bár előzményei már a szocialista időszak vidéki ipartelepítésének eszköztárában is megjelentek (Kőszegfalvi 1978; Pál, Zsigó 1981), látványos karriert a rendszerváltás utáni, külföldi tőkevonzásra építő exportorientált gazdaságfejlesztési politika keretében futott be. Az önkormányzatok úgy vélik, hogy egy-egy ipari park nagymértékben javítja településük vonzerejét az új telephelyeket kereső befektetők körében, elősegíti letelepedésüket, és így hozzájárul saját bevételeik növeléséhez, a munkanélküliség csökkentéséhez. A gazdasági szerkezetváltás és a munkahelyteremtés mellett az ingatlanhasznosítás igénye is gyakori motivációként jelent meg az ipari parkok létrehozásában (Kiss 2013). A lehetőségek kihasználása ugyanakkor komoly erőfeszítéseket követelt az önkormányzati vezetőktől: ki kellett jelölni az érintett területeket, meg kellett építeni az ipari parki infrastruktúrát, amelyet aztán reklámozni kellett a potenciális befektetők, vállalatok számára. A városok között nagy különbségek figyelhetők meg: míg egyes helyeken csak a területek kijelöléséig jutottak el, másutt az igények nö- 
vekedése az ipari parkok többszöri bővítését tette szükségessé, és az ipari parkok maguk is a helyi gazdaság jelentős szereplőivé váltak.

Tanulmányunk célja az ipari parkok működésének és helyi gazdaságfejlesztésben betöltött szerepének elemzése Magyarország második legnépesebb városában, Debrecenben. Áttekintjük az ipari parkok megjelenését a településés gazdaságfejlesztési tervekben és stratégiákban, összehasonlítjuk a létrehozott ipari parkok jellemzőit, valamint bemutatjuk az ipari parkokban működő cégek szerepét a város gazdasági életében. Az első részben az ipari park meghatározásával foglalkozunk, a második részben bemutatjuk Debrecen gazdaságának fejlődését. Kutatásunk során többféle forrást használtunk fel. A szakirodalom feldolgozása mellett támaszkodtunk a rendszerváltás utáni helyi fejlesztési dokumentumokra, a városban müködő ipari parkok honlapjaira, a Creditreform online céginformációs adatbázisára, továbbá - terepmunka keretében - feltérképeztük az ipari parkokba települt vállalkozásokat. (Vizsgálatunk elsősorban az ipari park címmel rendelkező ingatlanokra terjed ki, így a müködtető által ilyen névvel ellátott, de jogszabály által el nem ismert objektumokról csak említést teszünk.)

\section{Az ipari parkok fogalma}

Az ipari parkok fogalmát két oldalról közelítjük: a tudomány álláspontjától és a hivatalos jogszabályok meghatározásától.

Az elmúlt évtizedekben a helyi gazdaságfejlesztéssel (Kozma 2002) és a regionális politikával (Rechnitzer 2002) foglalkozó kutatók több szempontból közelítették meg az ipari parkok kérdéskörét. Rögzítették azokat az elemeket, amelyek teljesülése esetén egy ingatlant ipari parknak lehet tekinteni (Lengyel, Imre, Kosztopulosz 2002; Rakusz 2000):

- Az ipari park területe tulajdonjogi szempontból rendezett, alap-infrastruktúrája műszakilag meghatározott; az ipari parknak van „gazdája”, amely a betelepült szervezetek számára üzleti alapon szolgáltatásokat nyújt; az ipari park infrastruktúrájának létrehozását az állam a legtöbb esetben támogatja, az ott elérhető szolgáltatások általában kedvezményes áron vehetők igénybe, az ipari parkon belül értékteremtés (nem kizárólag ipari tevékenység!) folyik.

- Az ipari parkokkal foglalkozó tudományos vizsgálatok az objektumok tágabb környezetét is kutatták, többek között elemezték a közlekedési hálózathoz füződő kapcsolataikat (Kiss, Tiner 2012), a területi versenyképességben betöltött szerepüket (Lux 2013), agglomerációs előnyöket generáló jellemzőiket (Faragó, Lux 2014), valamint az ipari parkok és az egyes gazdasági ágazatok közötti viszonyrendszert (Lukács 2013; Molnár 2013b). 
- Az ipari parkokkal kapcsolatos vizsgálatok harmadik csoportja az objektumok különböző típusait különítette el: meghatározta sajátosságaikat, illetve a hozzájuk kötődő előnyöket és hátrányokat. Az elhelyezkedés és kialakulás módja szerint alapvetően két típust (barnamezős és zöldmezős ipari parkok) különböztettek meg (Grasselli 1996; Kiss 2001, 2013; Nikodémus 2002). Hat csoportba sorolták a magyarországi objektumokat: zöldmezős park (pl. Győri Ipari Park, Hatvani Ipari Park); korábban már a területen működő vállalkozásokat integráló parkok, jelentős zöldmezős területekkel (pl. Esztergomi Ipari Park, Orosházi Ipari Park); korábbi katonai területek, jelentős zöldmezős területekkel (pl. Pápai Ipari Park); egykori ipari területek, döntően betelepült vállalkozásokkal, illetve üres ipari épületekkel (pl. Ózdi Ipari Park); agrárjellegű ipari parkok (pl. Térségi Ipari Park - Pacsa, Homokhát Térségi Agrár-Ipari Tudományos és Technológiai Park - Mórahalom); logisztikai központokból kialakult ipari parkok (pl. Harbor Ipari Park - Budapest).

- Egy másik megközelítés az ipari parkokban folyó tevékenységet vette alapul, és erre támaszkodva is több kategóriát különített el (Benko 1992; Kullmann 2000; Rakusz 2000): tudományos parkok, technológiai parkok, kereskedelmi parkok, innovációs központok, hagyományos ipari parkok.

A témával foglalkozó nemzetközi szakirodalom az első két típusra koncentrál, ezen belül is kiemelt figyelmet fordít a tudományos parkokra, mivel együttműködve a felsőoktatási intézményekkel fontos szerepet játszhatnak a kutatás-fejlesztés során keletkezett innovációk, szabadalmak hasznosításában (Barta 2002; Dusek, Lukovics 2014). Az elemzések során a kutatók több területre koncentráltak. Az ipari parkok időbeli fejlődésében (Annerstedt 2006; Haselmayer 2004) három szakaszt különítettek el. Az első generációs ipari parkok alapvetően az egyetemek kezdeményezésére és azok szomszédságában jöttek létre, inkubációs lehetőséget biztosítottak a start-up cégek és kapcsolódó szolgáltatások számára, illetve lehetőséget teremtettek arra, hogy a potenciális befektetők részesüljenek a K+F-tevékenységből származó know-how eredményeiből. Az ipari park - amelyet általában az egyetem által létrehozott és irányított alapítvány vagy cég vezet - egyik fö célja az egyetem gazdasági törekvéseinek segítése. A második generációs ipari parkok esetében a fö mozgatóerő már az üzleti szférából érkezik, amely érdekelt az innovációra támaszkodó vállalatok alapításában és növekedésében. Az ipari park többnyire független és nagyobb távolságban található az egyetemektől. Az ipari park vezetése magánvállalatok kezében van, az állami és az akadémiai szféra tevékenysége elsősorban az ipari parkra vonatkozó jogszabályok kidolgozására terjed ki. A harmadik generációs ipari parkok - leggyakrabban városi környezetben elhelyezkedve - a tudomány, a kormányzat és az ipar közötti kapcsolatok eredményeként jönnek létre, és egyre fontosabb szerepet töltenek be nemcsak a helyi és regionális, hanem a globális innovációs tevékenységekben is. Az ipari park vezetése az innovációmenedzsmentben jártas szakértők által irányított szervezet kezében van, amelynek fó célja, hogy az innováció katalizátoraként a város életének szerves részévé tegye. 
A kutatások arra is választ kerestek, hogy előnyökkel jár-e (és ha igen, milyen tekintetben) a tudományos és technológiai parkokban történő letelepedés. A tanulmányok egy része (Squicciarini 2009; Lamperti, Mavilia, Castellini; Vásquez-Urriagó, Barge-Gil, Rico 2016) arra hivatkozott, hogy az ilyen telephelyválasztás növeli a vállalatok innovatív együttműködésének valószínűségét, segíti növekedésüket, illetve kutatási és szabadalmi tevékenységüket. Mások megfogalmaztak olyan véleményeket is (Colombo, Delmastro 2002; Liberati, Marinucci, Tanzi 2016; Löfsten, Lindelöf 2002; Ramírez-Alesón, Fernandéz-Olmos 2018), amelyek szerint a tudományos-technológiai parkok csak high-tech „fantáziának" tekinthetők: nincs lényeges különbség az ilyen parkokban és az azokon kívül települt cégek innovációs tevékenysége között. Egyes kutatások (Díez-Vial, Fernandéz-Olmos, 2017; Syed, Klaiber, Sheldon 2018) rámutattak arra, hogy a vállalatok jellemzői is fontosak: nagyságuk, integrálódásuk az ország gazdaságába nagymértékben befolyásolja az ipari parkban végzett tevékenységeiket. Utóbbi kérdéskör túlmutat a tudományos parkok és az innováció kérdéskörén: a globális gazdasági szereplők helyi beágyazódása általában a globális-lokális kapcsolatok értelmezési kereteként, globális termelési hálózatokon belüli pozícióik és előrelépésük szempontjából is jól alkalmazható megközelítés (Józsa 2019). Az ipari parki kutatások kiterjedtek a sikeresség feltételeinek elemzésére is. A vizsgálatok (Albahari et al. 2018; Díez-Vial, Montoro-Sánchez 2016; Guadix et al. 2016; Hobbs, Link, Scott 2017) a sikerességet befolyásoló tényezők közül kiemelték az ipari parkok korát (ebből a szempontból az újonnan alapított és a régóta működő ipari parkok kínáltak jobb lehetőségeket, míg a „középkorúak” gyengébben működtek), az ipari park és menedzsmentjének nagyságát, az egyetemek közelségének pozitív hatását, valamint a régió technológiai fejlettségi szintjének szerepét (az alacsonyabb technológiai fejlettségü régiók tudományos és technológiai parkjaiban múködő cégek jobban teljesítenek, mint a fejlett régiók parkjaiban letelepedett vállalatok).

Magyarországon a rendszerváltás után a helyi önkormányzatok gazdaságfejlesztési tevékenységének fontos elemét képezte a gazdasági szereplők igényeit kielégítő, megfelelő infrastruktúrával rendelkező ipari parkok kialakítása. Az első fejlesztések Győrben és Székesfehérváron valósultak meg (Kiss 2013). Az ipari parkok alapítását célzó különböző kezdeményezések ugyanakkor problémákat okoztak (felmerült az a kérdés, hogy melyik politikai-gazdasági szereplő kaphat e célra központi állami támogatást). Az 185/1996. (XII. 11.) számú kormányrendelet kimondta, hogy az ipari park címet pályázat útján lehet megszerezni, és csak e cím birtokában lehet elindulni azokon a pályázatokon, amelyek az infrastruktúra kiépítésére vonatkoznak. Az elmúlt 20 évben több olyan minisztériumi és kormányrendelet jelent meg, amelyek szabályozták a cím odaítélésének feltételeit. Az érintett jogszabályoknak voltak közös elemei, amelyek például a pályázók személyére (helyi önkormányzatok, illetve azok társulásai, gazdasági társaságok) és a dokumentumok kidolgozására (megvalósíthatósági tanulmány) vonatkoztak. Szigorodtak is az idők folyamán a feltételek: 2007-től 
például csak olyan objektum nyerheti el az ipari park címet, amelyben már legalább 5 vállalkozás működik, összesen 100 föt foglalkoztatva (2/2007. (I. 18.) kormányrendelet, amely módosítja az 186/2005. (IX. 13.) kormányrendeletet az ipari park címről és az ipari parkok fejlesztését szolgáló rendszer működéséről).

Az ipari parkok magyarországi jogszabályi definícióját a 2010-es években alkották meg (a korábban említett jogszabályok csak azokat a feltételeket fogalmazták meg, amelyek teljesülése esetén egy ingatlan megkaphatta az ipari park címet). A területfejlesztésről és a területrendezésről szóló 1996. évi XXI. törvény 2013-as módosítása (2013. évi CCXVI. törvény) értelmében az ipari park „általános ipar- és területfejlesztéssel foglalkozó, infrastruktúrával ellátott területtel rendelkező, fejlesztő, termelő és szolgáltató tevékenységet folytató működésre és innovációra törekvő, ipari park címmel rendelkező szervezet”. A törvény 2015-os módosítása (2015. évi CLXXXVI. törvény) eltérő megközelítést alkalmazott, és az ingatlanra helyezte a hangsúlyt: „infrastruktúrával ellátott olyan terület, ahol elsősorban termelő és feldolgozóipari tevékenységet végző, valamint innovációra törekvő vállalkozások találhatóak". Emellett az ipari parkokat differenciálták is: előbb az „integrátor” és a „kistérségi gazdaságfejlesztő” ipari park címet vezették be (186/2005. (IX.13.) kormányrendelet az „ipari park" címről és az ipari parkok fejlesztését szolgáló rendszer működéséről), majd a 2005. évi szabályozást hatályon kívül helyező, ipari parkokról szóló 297/2011. (XII. 22.) kormányrendelet nyomán megszületett a „tudományos és technológiai park" kategóriája. A szabályozás szerint a tudományos és technológiai park „az az ipari park, mely elsődlegesen tudásintenzív, technológiai innovációval foglalkozó vállalkozások fejlődésének elősegítésére jött létre vagy ilyenként müködik". Elemzésünkben - az ipari parkokkal kapcsolatos fogalmi polémiákat kerülendő - azon objektumokra fókuszálunk, melyek rendelkeznek az ipari park címmel.

Az ipari park címmel rendelkező objektumok száma Magyarországon a 2000 utáni első években jelentősen növekedett: eleinte évi 25-30, majd a 2000-es évek közepétől évi 8-10 ipari parkkal. Ezt követően stagnálás volt jellemzö, majd 2015-2016 folyamán 32 ipari park engedélyt be kellett vonni, mivel a beruházók nem tudták teljesíteni az ipari park múködési feltételeit (az ipari parkokról szóló 297/2011. (XII. 22.) Korm. rendeletben előírt 10 vállalkozás és 350 fős foglalkoztatás a pályázat elnyerésétől számított 5. év végére). Így 2016ban hivatalosan 196 ipari park működött Magyarországon, melyek közül 8 objektum a tudományos és technológiai park címet is elnyerte (Tájékoztató 2016). Ennek némiképp ellentmond, hogy az Ipari, Tudományos-, Innovációs-, és Technológiai Parkok Egyesület (IPE) - vélhetően aktualizált - honlapján 2019 elején 193 ipari parkra és 18 tudományos és technológiai parkra történt utalás. Az ipari parkok méreteiben, a betelepült gazdasági szereplők teljesítményében, a helyi gazdaságot élénkítő szerepükben nagy különbségek mutatkoznak. A legjelentősebb ipari parkok a Dunántúl északi részén müködnek: a legutóbbi átfogó 
tudományos vizsgálat elsősorban Székesfehérvár, Mór, Tatabánya, Komárom, Esztergom, Győr, Szombathely és Sárvár ipari parkjainak teljesítményét emelte ki (Kiss 2013).

\section{Debrecen gazdasága a rendszerváltás után}

Debrecen a mérsékeltebb gazdasági dinamikát felmutató nagyvárosaink közé tartozik a rendszerváltás után (az elemzésben nem vettük figyelembe Budapest adatait). Transzformációs válsággal összefüggő munkahelyvesztesége az 1990-es években ugyan meghaladta a vidéki nagyvárosok átlagát, de az ezredforduló utáni növekedése is gyorsabb volt az említett vidéki nagyvárosokhoz képest, így a két évtizedre vetítve - Szeged és Pécs mellett - Debrecen mutatója áll legközelebb a csoportátlaghoz. A legnagyobb vidéki foglalkoztató pozícióját ugyan elhódította a mélyebb strukturális válságot átélt Miskolctól, lakosságszámra vetített munkahelysűrűsége azonban mindvégig az egyik legalacsonyabb (1. táblázat). 2011-ben a vidékről bejárók által betöltött munkahelyek aránya Szeged mellett Debrecenben volt a legkisebb (21-22\%), és bár a gazdaságilag inaktív népesség aránya viszonylag csekély volt, munkanélküliségi rátája a nagyvárosok között a magasabbak közé tartozott.

A Nemzeti Foglalkoztatási Szolgálat adatai szerint az ezredforduló után a város munkanélküliségi adatai elmaradtak ugyan az országos átlagtól, de a nagyvárosok között Debrecen már akkor is csak Miskolcot volt képes érdemben megelőzni. A 2008-as válság idején - valamennyi nagyvároshoz hasonlóan - romlottak mutatói: a kedvezőtlen trend csak 2012 után fordult meg, miközben a munkanélküliségi ráta csökkenésének mértéke ezután is elmaradt az országos

1. táblázat: A helyben foglalkoztatottak abszolút és 100 lakosra jutó száma a vidéki nagyvárosokban Locally employed people in larger cities (number and per 100 inhabitants)

\begin{tabular}{|c|c|c|c|c|c|c|}
\hline \multirow[t]{3}{*}{ Nagyvárosok } & \multicolumn{6}{|c|}{ Helyben foglalkoztatottak száma (2011) Helyben foglalkoztatottak száma 100 lakosra (fó) } \\
\hline & 1990 & 2001 & Fö & 1990 & 2001 & 2011 \\
\hline & \%-ában & \%-ában & & & & \\
\hline Debrecen & 88 & 111 & 96419 & 52 & 41 & 46 \\
\hline Győr & 98 & 102 & 79807 & 63 & 60 & 62 \\
\hline Kecskemét & 103 & 115 & 56760 & 54 & 46 & 51 \\
\hline Miskolc & 67 & 104 & 79917 & 60 & 42 & 48 \\
\hline Nyíregyháza & 94 & 114 & 60280 & 56 & 44 & 50 \\
\hline Pécs & 85 & 101 & 72197 & 50 & 44 & 46 \\
\hline Szeged & 89 & 111 & 78419 & 52 & 42 & 47 \\
\hline Székesfehérvár & 100 & 96 & 68731 & 63 & 67 & 68 \\
\hline Összesen & 88 & 106 & 592530 & 52 & 47 & 51 \\
\hline
\end{tabular}

Forrás: KSH népszámlálás 1990, 2001, 2011. 
1. ábra: Munkanélküliségi ráta a vidéki nagyvárosokban Unemployment rate in Hungarian larger cities (\%)

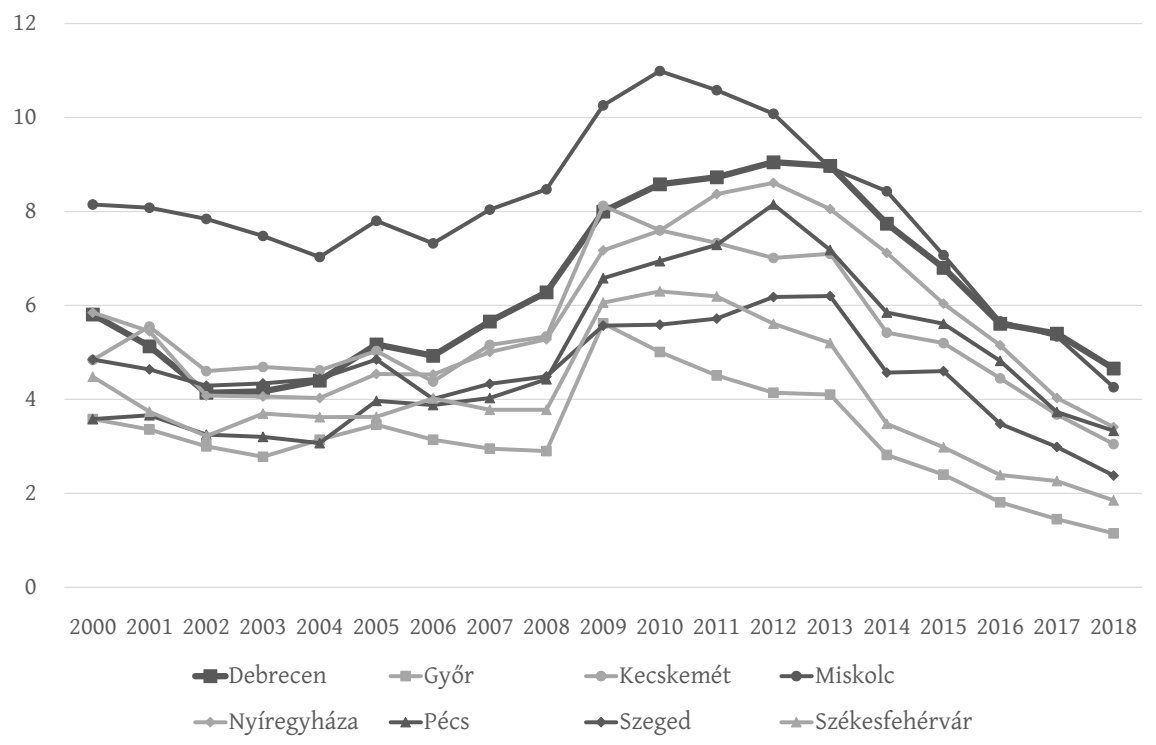

Forrás: az NFSZ adatai alapján.

átlagtól. Debrecen mutatója 2010-től az országos átlag fölé került, 2017-ben pedig Miskolc is megelőzte (1.ábra).

A nagyvárosok között kedvezőtlen foglalkoztatási adatok ellenére Debrecen gazdasága - a város méreteiből adódóan - az ezredforduló utáni időszakban is jelentős. A települési gazdasági erő három komponens (regisztrált vállalkozások, helyi adóbevételek és adóköteles jövedelmek) alapján, a megyei GDP-értékek dezaggregálásával becsült értéke (a módszertan leírásáról lásd: Lőcsei, Nemes Nagy 2003; Pénzes 2014) Debrecen és Győr versenyét mutatja a legnagyobb vidéki városi gazdaság pozíciójáért. Ezt a versenyt ugyanakkor Debrecen mindinkább elveszíteni látszik a 2010-es években (2. ábra). A teljesség kedvéért említenénk meg, hogy a lakosságszámra vetített gazdasági erőben - a mezőnyből tartósan kiemelkedő Győr és Székesfehérvár kivételével - csekély különbségek voltak a magyarországi nagyvárosok között. E mutató alapján ugyanakkor a legnagyobb közintézményrendszerrel rendelkező regionális központok - köztük Debrecen - vannak előnyben: ha csak a szűkebb vállalkozói szféra teljesítményeit vesszük számításba, akkor Magyarország második legnépesebb települése inkább Székesfehérvárral van versenyben a második legjelentősebb vidéki gazdaság pozíciójáért, ami nemcsak a kettős könyvvitelt vezető társas vállalkozások összesített teljesítménymutatóival támasztható alá (Molnár et al. 2018), hanem a város Győrt és Székesfehérvárt követő helyi adóbevételeivel is.

Debrecen a rendszerváltás után a gyorsabban tercierizálódó vidéki nagyvárosaink közé tartozik: a mezőgazdaság a vidéki nagyvárosok átlagát meghala- 
2. ábra: A vidéki nagyvárosok gazdasági ereje (milliárd forint)

Economic power of Hungarian larger cities (billion HUF)

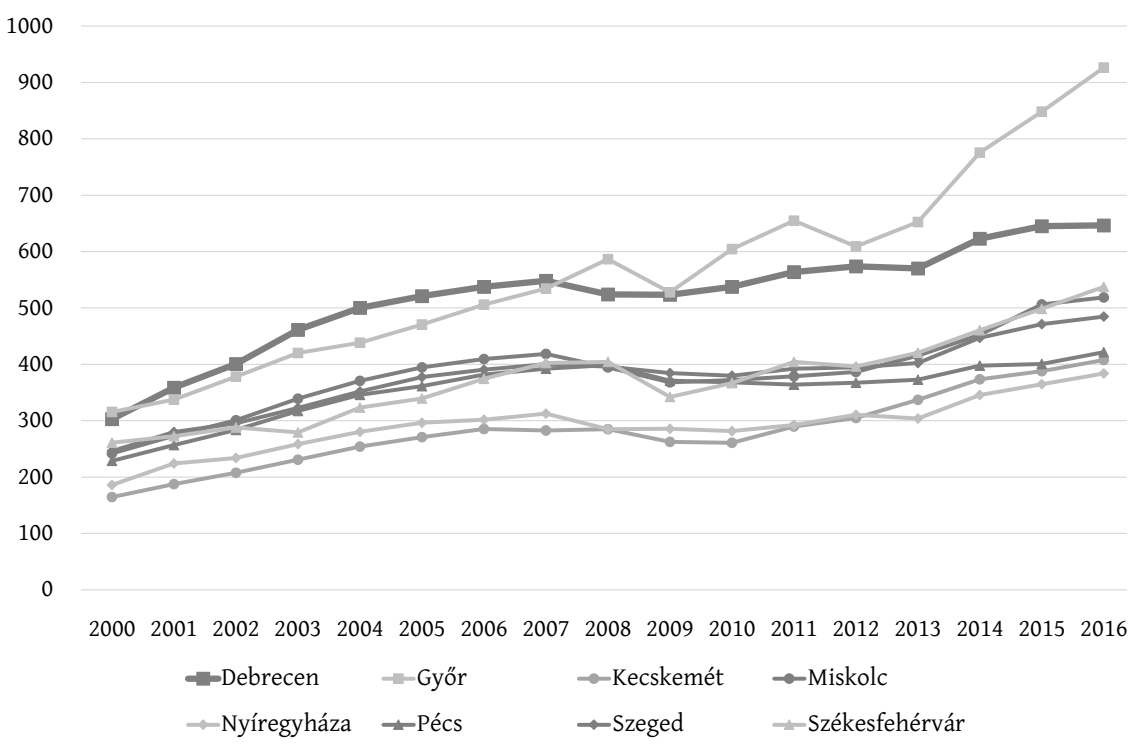

Forrás: a KSH, a MÁK és a NAV adatai alapján.

dó súllyal szerepel, miközben az ipar - a másik két teljes értékű regionális központhoz, Szegedhez és Pécshez hasonlóan - csoportátlagot alulmúló mértékben jelenik meg a legutóbbi népszámlálás adatai szerint. Budapest utáni legjelentősebb foglalkoztatóként Debrecen rendelkezett 2011-ben a legtöbb munkahellyel a szolgáltató szektorban és a mezőgazdaságban, míg az iparban foglalkoztatottak abszolút száma alapján Győr és Székesfehérvár után következett. Gazdasági szerkezetét - a legtöbb vidéki nagyvárossal összevetve - diverzifikáltság jellemzi. Figyelemre méltó a város közép- és potenciális középvállalati szektorának abszolút értelemben és népességszámra vetítve is nagy száma (2. táblázat). E körben a kereskedelem és egyéb szolgáltatások mellett az építőipar és az élelmiszergazdaság vállalatai jelennek meg elsősorban, a nagyobb cégek között pedig - az ezredforduló után leépült élőmunka-igényes könnyüipar kivételével - látványos a hagyományos feldolgozóipari ágak (húsipar, baromfifeldolgozás, tejipar, tartósítóipar, malom- és sütőipar, dohánygyártás, nyomdaipar, gyógyszergyártás, müanyag-feldolgozás, fémipar, csapágygyártás, vasúti járműgyártás, orvosi műszergyártás) máig stabil jelenléte. Szerencsés körülmény, hogy Debrecen méreteihez képest nincs igazán kiemelkedő gazdasági szereplő, miközben a legnagyobb (1000 fó feletti) magánfoglalkoztatók körében - a város sokoldalúságát tükrözve - képviselteti magát az élelmiszergazdaság (Tranzit Csoport), a gyógyszergyártás (TEVA), az elektronikai ipar (NI) és a gépgyártás (FAG), illetve az ezredforduló után felfutottak a megosztott szolgáltatóközpontok (IT Services) is. Egyaránt fontos Debrecen gazdaságában - a felsőoktatási és $\mathrm{K}+\mathrm{F}$ háttérrel is ki- 
2. táblázat: Nagy-, közép- és potenciális középvállalatok abszolút és ezer lakosra jutó száma a magyarországi nagyvárosokban

Big, medium-sized and potentially medium-sized enterprises in Hungarian larger cities (number and per 1000 inhabitants)

\begin{tabular}{|c|c|c|c|c|c|c|}
\hline \multirow[t]{2}{*}{ Nagyvárosok } & \multicolumn{3}{|c|}{$\begin{array}{l}\text { Nagy-, közép-és potenciális középválla- } \\
\text { latok száma }(2015, d b)\end{array}$} & \multicolumn{3}{|c|}{$\begin{array}{l}\text { Nagy-, közép- és potenciális középválla- } \\
\text { latok száma } 1000 \text { lakosra }(2015, d b)\end{array}$} \\
\hline & 250 fo felett & $50-249 f_{0}^{\prime \prime}$ & 20-49 fo & 250 fo felett & 50-249 fo & 20-49 fó \\
\hline Debrecen & 22 & 107 & 247 & 0,11 & 0,53 & 1,22 \\
\hline Győr & 26 & 97 & 151 & 0,20 & 0,75 & 1,17 \\
\hline Kecskemét & 16 & 65 & 140 & 0,14 & 0,58 & 1,25 \\
\hline Miskolc & 18 & 59 & 109 & 0,11 & 0,37 & 0,69 \\
\hline Nyíregyháza & 8 & 56 & 153 & 0,07 & 0,47 & 1,30 \\
\hline Pécs & 7 & 48 & 151 & 0,05 & 0,33 & 1,04 \\
\hline Szeged & 19 & 61 & 180 & 0,12 & 0,38 & 1,11 \\
\hline Székesfehérvár & 23 & 69 & 150 & 0,23 & 0,70 & 1,53 \\
\hline Összesen & 139 & 562 & 1281 & 0,12 & 0,50 & 1,14 \\
\hline
\end{tabular}

Forrás: KSH-adatok alapján.

egészülő - tradicionális élelmiszergazdaság, amely szervező szerepet játszik az ország egyik legjelentősebb mezőgazdasági megyéjében, valamint a modern nagyvárosi tevékenységnek számító szolgáltatóközpontok (Shared Service Center, SSC), amelyek (Székesfehérvárral holtversenyben élen a vidéki nagyvárosok között) mintegy 3-4 ezer alkalmazottat foglalkoztatnak. Hozzátartozik a helyi gazdaságról alkotott képhez, hogy Debrecenben - Szegedhez és Pécshez hasonlóan - az egyetem a legnagyobb foglalkoztató, kiterjedt közigazgatási-közszolgáltatási profiljának megfelelően a honvédség is fontos szerepet játszik a foglalkoztatásban. Debrecen a kereskedelmi és egyéb szálláshelyeken eltöltött vendégéjszakák száma alapján - Miskolchoz, Győrhöz és Szegedhez hasonlóan - Magyarország 15 leglátogatottabb települése közé tartozik, vendégforgalma azonban egyharmadát sem éri el a szomszédos Hajdúszoboszló értékének.

Debrecen gazdaságának erős regionális pozícióit és a helyi gazdaságfejlesztés fontosságát jól mutatja, hogy Hajdú-Bihar megye települési gazdasági erejének mintegy 50-60\%-át, a kettős könnyvitelt vezető társas vállalkozások bruttó hozzáadott értékének körülbelül 60-70\%-át a megyeszékhely adta az elmúlt két évtizedben, s ez a nagyvárosok között a legmagasabb értékek egyike (helyzete Pécshez és Szegedhez hasonlítható).

\section{Az ipari parkok Debrecen gazdaságfejlesztési terveiben}

Debrecen gazdaságának rendszerváltás utáni nehézségei - melyek a nagyvállalati szféra átszervezésével járó munkanélküliség-növekedéssel, reáljövedelem- 
csökkenéssel, egyes ipari és katonai hasznosítású területek rozsdaövezetté válásával már az 1990-es évek elején komoly kihívást jelentettek - igen jelentős, korábban ismeretlen jellegü erőfeszítéseket követeltek meg a helyi önkormányzattól. Már a Hajdú-Bihar megye rövid és középtávú fejlesztési feladatairól szóló 1068/1993. (X. 26.) számú kormányhatározat is fontosnak tartotta - több egyéb fejlesztési igény megfogalmazása (pl. a repülőtér polgári hasznosítása) mellett - a debreceni innovációs és ipari park létrehozását. A megyeszékhely első településfejlesztési tervének tekinthető, 1996-ban elfogadott Várospolitikai programban is a feladatok között szerepelt „a város vonzóvá tétele a külföldi tőkebefektetések számára, a meglévő technikai és szellemi infrastruktúra jobb kihasználásának elősegítése”, a program konkrét lépései között azonban nem említettek ipari parkokat. Debrecen gazdaságfejlesztési tevékenységét az 1990-es évtizedben koordináló Debreceni Regionális Gazdaságfejlesztési Alapítvány ugyanakkor két területen is tett lépéseket az ipari parkok fejlesztése érdekében. Egyrészt az 1996-ban kidolgozott, egymásra épülő elemekből (pl. inkubátorház, vállalkozói park) álló gazdaságfejlesztési rendszer utolsó egységeként képzelte el az ipari parkot mint a nagyobb méretű tömegtermelést megvalósító vállalatok számára telephelyet biztosító ingatlant, másrészt a készülő fejlesztésről több kiadványban tájékoztatták a potenciális befektetőket is.

2000 után a Debrecen gazdaságfejlesztésével foglalkozó első komplex tervek két-három szintből épültek fel: az alsó szint (operatív feladat, operatív tevékenység) foglalkozott az ipari parkokkal (3. táblázat). Az ipari parki helyszínek mind konkrétabb meghatározása az ingatlanok továbbfejlesztéséhez kötődött. A Déli Ipari Park infrastruktúra-fejlesztési igénye egyrészt a terület kiváló logisztikai fekvésével (a repülőtér közelsége), másrészt a hasznosításhoz elengedhetetlen rendkívül költséges beruházások (a vonalas infrastruktúra kiépítése: út, vasút stb.) szükségességével függött össze. A 2010-es évtizedben új elemként jelent meg két ipari park esetében is az elérhetőség javítása (vagyis az ipari parkok ugyan már teljes kapacitással működtek, miközben az elérhetőségük akadályozta a normális működést).

$\mathrm{Az}$ operatív feladatok jelentős része az elmúlt időszakban megvalósult. Több gazdasági célra alkalmas területet is fejlesztettek, melyek közül négy - részben magántulajdonban lévő - objektum az ipari park címet is elnyerte. Megkezdődött a Déli Ipari Park infrastruktúrájának kiépítése és a debreceni repülőtér logisztikai fejlesztése. Jelentősen nőtt a Debreceni Regionális és Innovációs Ipari Park területe, és ugyanez várható az Egyetemi Ipari Park esetében is. A tervek szerint 2019-ben kezdődik el a Debreceni Egyetemi Ipari Park elérhetőségét javító beruházás - közvetlen kapcsolattal a 33. számú főközlekedési úthoz. A Nyugati Ipari Park bővítése és a Határ úti Ipari Park elérhetőségének javítása egyelőre elmaradt. 
3. táblázat: Az ipari parkok megjelenése Debrecen fejlesztési terveiben Industrial parks of Debrecen in the development documents

\begin{tabular}{|c|c|c|c|}
\hline Terv & $\begin{array}{l}\text { Stratégiai program, } \\
\text { prioritás, középtávú } \\
\text { tematikus cél, részcél }\end{array}$ & $\begin{array}{l}\text { Operatív program, } \\
\text { intézkedés }\end{array}$ & Operatív feladat, operatív tevékenység \\
\hline \multirow[t]{3}{*}{$\begin{array}{l}\text { Debrecen Me- } \\
\text { gyei Jogú Város } \\
\text { Gazdaságfejlesz- } \\
\text { tési Koncepciója } \\
(2000)\end{array}$} & $\begin{array}{l}\text { A termelő szféra } \\
\text { versenyképességé- } \\
\text { nek erősítése }\end{array}$ & $\begin{array}{l}\text { Befektetésösztön- } \\
\text { zés }\end{array}$ & $\begin{array}{l}\text { Ipari parkok koncepcionálisabb megfo- } \\
\text { galmazása; a telephelyi infrastruktúra } \\
\text { fejlesztése; az üzleti infrastruktúra fej- } \\
\text { lesztése }\end{array}$ \\
\hline & $\begin{array}{l}\text { A logisztikai és tran- } \\
\text { zitszerepkör erősí- } \\
\text { tése }\end{array}$ & $\begin{array}{l}\text { A repülőtérre ala- } \\
\text { pozott logisztika } \\
\text { fejlesztése }\end{array}$ & Területkijelölések és azok fejlesztése \\
\hline & & $\begin{array}{l}\text { A vasútra és köz- } \\
\text { útra alapozott lo- } \\
\text { gisztika fejlesztése }\end{array}$ & Területkijelölések és azok fejlesztése \\
\hline $\begin{array}{l}\text { Debrecen Me- } \\
\text { gyei Jogú Város } \\
\text { 2004-2006 kö- }\end{array}$ & gfejlesztés & $\begin{array}{l}\text { A termelői szféra } \\
\text { versenyképesség- } \\
\text { ének fejlesztése }\end{array}$ & $\begin{array}{l}\text { Ipari park és ipari tevékenységre alkal- } \\
\text { mas telephelyek infrastrukturális fej- } \\
\text { lesztése }\end{array}$ \\
\hline $\begin{array}{l}\text { zötti operatív } \\
\text { fejlesztési prog- } \\
\text { ramja (2003) }\end{array}$ & & $\begin{array}{l}\text { A logisztikai és } \\
\text { tranzitszerep erő- } \\
\text { sítése }\end{array}$ & $\begin{array}{l}\text { A logisztikai létesítmények és szervezeti } \\
\text { keretek fejlesztése }\end{array}$ \\
\hline $\begin{array}{l}\text { Debrecen Me- } \\
\text { gyei Jogú Város } \\
\text { 2007-2013 kö- } \\
\text { zötti fejlesztésé- } \\
\text { nek stratégiai és } \\
\text { operatív prog- } \\
\text { ramja (2006) } \\
\end{array}$ & $\begin{array}{l}\text { A hatékonyabb gaz- } \\
\text { daság fejlesztéséhez } \\
\text { szükséges infra- } \\
\text { struktúra megte- } \\
\text { remtése }\end{array}$ & $\begin{array}{l}\text { A gazdaság igé- } \\
\text { nyeit kielégítő inf- } \\
\text { rastruktúra-fej- } \\
\text { lesztés }\end{array}$ & $\begin{array}{l}\text { A Déli Ipari Park infrastruktúrájának ki- } \\
\text { építése; a Debreceni Regionális és Inno- } \\
\text { vációs Ipari Park bővítése; az Egyetemi } \\
\text { Ipari Park infrastruktúrájának bővítése; } \\
\text { a logisztikai központok által kínált szol- } \\
\text { gáltatások színvonalának fejlesztése; a } \\
\text { Nyugati Ipari Park bővítése }\end{array}$ \\
\hline $\begin{array}{l}\text { Debrecen Me- } \\
\text { gyei Jogú Város } \\
\text { Integrált Város- } \\
\text { fejlesztési Stra- } \\
\text { tégiája (2007) }\end{array}$ & $\begin{array}{l}\text { A gazdaság igényeit } \\
\text { kielégítő infrastruk- } \\
\text { túra-fejlesztés }\end{array}$ & - & $\begin{array}{l}\text { A Debreceni Déli Ipari Park infrastruktú- } \\
\text { rájának kiépítése; a Debreceni Regionális } \\
\text { és Innovációs Ipari Park bővítése; a lo- } \\
\text { gisztikai központok által kínált szolgálta- } \\
\text { tások színvonalának fejlesztése }\end{array}$ \\
\hline $\begin{array}{l}\text { Debrecen Me- } \\
\text { gyei Jogú Város } \\
\text { Településfej- } \\
\text { lesztési Koncep- } \\
\text { ciója 2014-2020 } \\
\text { (2014) }\end{array}$ & $\begin{array}{l}\text { A nemzetközileg } \\
\text { versenyképes gazda- } \\
\text { ság igényeit kielé- } \\
\text { gítő infrastruktúra- } \\
\text { fejlesztés, a gazda- } \\
\text { sági szereplőket tá- } \\
\text { mogató környezet } \\
\text { kialakítása }\end{array}$ & - & $\begin{array}{l}\text { A Debreceni Déli Ipari Park infrastruktú- } \\
\text { rájának kialakítása; a Határ úti Ipari Park } \\
\text { és a Debreceni Egyetemi Ipari Park elér- } \\
\text { hetőségének a javítása; a Debreceni Re- } \\
\text { pülőtér logisztikai célú fejlesztése }\end{array}$ \\
\hline
\end{tabular}

Forrás: Euro-Régió Ház 2006, 2007; Euro-Régió Ház, INNOVA 2014; Excellence 2003; VÁTI, Euro-Régió Ház 2000. 


\section{A debreceni ipari parkok jellegzetességei}

Debrecenben a befektetésre alkalmas területek közül négy tekinthető hivatalosan is ipari parknak (3. ábra). A Debreceni Regionális Innovációs Tudományos és Technológiai Park 1997-ben, a Debreceni Egyetem Tudományos és Technológiai Innovációs Park és a Logisztikai Szolgáltató Központ és Ipari Park 1999-ben, míg a Debreceni Nyugati Ipari Park 2000-ben kapta meg a címet. (A barnamezős Daniella Ipari Park az egykori Beloiannisz Híradástechnikai Gyár területén, a Hanwha Tech Debrecen a Magyar Gördülőcsapágy Művek területén és a Lion Office Center a hajdani dohánygyár területén nem éri el a hivatalos minősítéshez szükséges méretet.) A korábbi ipari parkoknál jóval nagyobb területű, körülbelül 200 hektár kiterjedésű Déli Ipari Park infrastruktúrájának kiépítése és vállalatokkal történő betelepítése csak az elmúlt években kezdődött, így beruházójuk még nem tudja teljesíteni a szükséges feltételeket.

A négy Ipari Park kialakulási körülményei különböztek egymástól, így eltérő szervezeti-működési modellt testesítenek meg.

- A Debreceni Regionális Innovációs Tudományos és Technológia Parkot (DRITTP) 1997-ben alapította a helyi önkormányzat, és hosszú ideig a Debreceni

3. ábra: Befektetésre alkalmas területek Debrecenben a 2010-es évtized közepén Potential investment areas in Debrecen (mid-2010s)

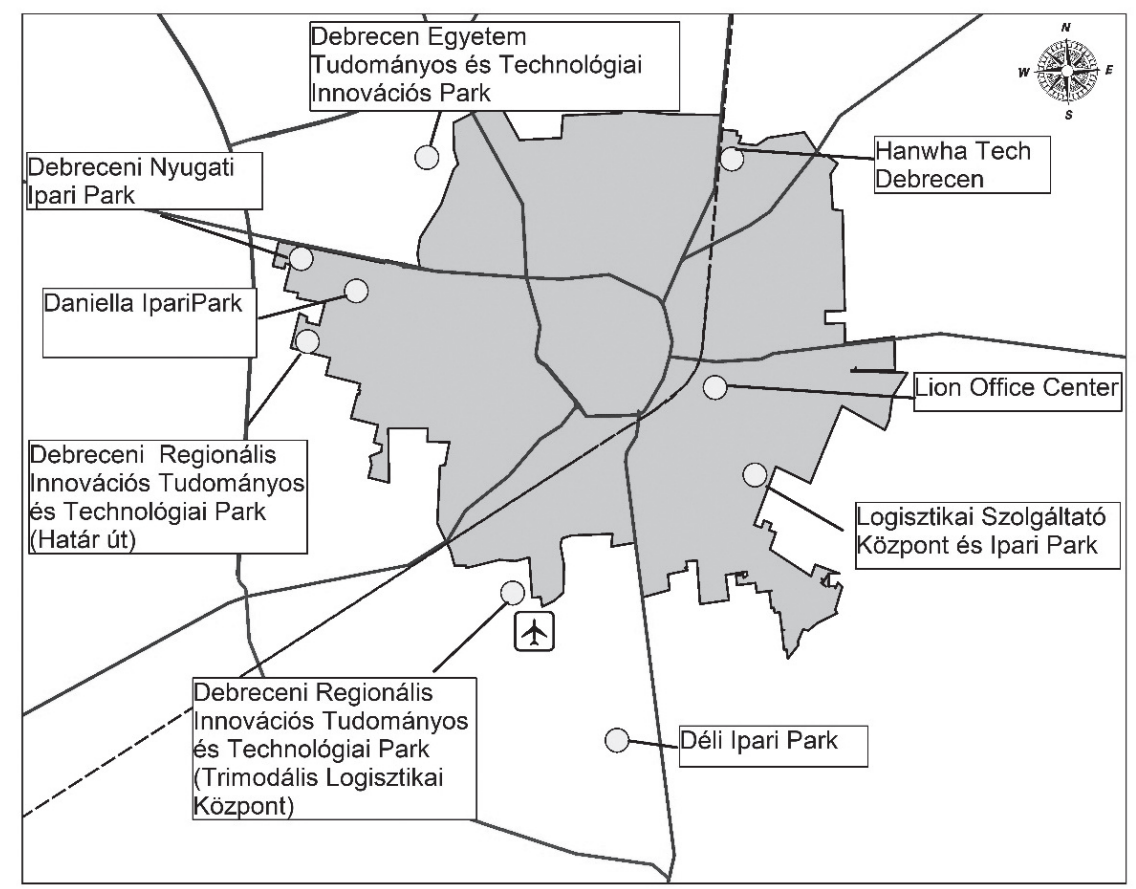

Forrás: EDC (2015) alapján saját szerkesztés. 
Vagyonkezelő Zrt. tagvállalatának számító Debreceni Innovációs és Ipari Park Kft. kezelésében működött. Az ipari park 100\%-os telítettsége utáni bővítéséhez - a magas költségek miatt - a holding már nem vállalta az önerő biztosítását, így 2005 után az ipari parkot a hazai tulajdonú Xanga Investment \& Development Group cégcsoport tagvállalata, a Debreceni Ipari Park Akadémia (DIPA) Kft. vette át. Az ingatlan fejlesztése azonban továbbra is az önkormányzat, illetve magánszereplők együttmüködésében valósult meg: nagyméretủ stratégiai cégek (National Instruments Europe Kft., FAG Magyarország Kft.) betelepítése, a helyi oktatási-képzési rendszer gazdasági szereplők igényei szerinti fejlesztése, illetve a közösségi közlekedés ipari park érdekei szerinti szervezése volt a kitüzött cél (Molnár 2013a). Az ipari parkot működtető DIPA Kft. egyrészt közvetlenül értékesíti az ingatlanokat, másrészt saját zöldmezős beruházásokat (irodaegységeket, kereskedelmi vagy ipari létesítményeket) valósít meg, melyeket aztán bérleményként kiad. Az objektum 2015-ben a tudományos és technológiai park címet is megkapta, területe kibővült: már magában foglalja a repülőtér mellett elhelyezkedő Trimodális Logisztikai Központot is.

- A Debreceni Egyetem Tudományos, Technológiai és Innovációs Park (DETTIP) üzemeltetője az egyetem 100\%-os tulajdonában álló UD TUTI Tudományos, Technológiai és Innovációs Park Nonprofit Közhasznú Kft. Az egyetem földrajzi közelségében kialakított ipari, technológiai telephely az akadémiai szektor, valamint a gazdasági szereplők közötti kölcsönös kapcsolatok építését és erősítését szolgálja (az objektum 2017 végén kapta meg a tudományos és technológiai park címet).

- A Logisztikai Szolgáltató Központ és Ipari Parkot (LSZKIP) szintén egy magántulajdonos, a nemzetközi szállítmányozó cégből komplex logisztikai szolgáltatásokat kínáló, országos hálózatot kiépített Trans-Sped csoporthoz tartozó DELOG Kft. üzemelteti. Az ipari park az anyavállalat által használt ingatlanok mellett további bérlőknek kínál raktárakat: 2017-ben összesen 6 csarnok, csaknem 40 ezer $\mathrm{m}^{2}$ alapterülettel müködött az ipari parkban.

- A Debreceni Nyugati Ipari Park (DNYIP) működési modelljében is a betelepült vállalkozásoknak értékesített, illetve bérleményként kiadott ingatlanok szerepelnek. A létesítményt a Nyugati Ipari Park Kft. müködteti, melynek minden vállalkozás a tagja, amely ingatlannal rendelkezik az ipari parkon belül (egy 2015-ben készített interjúban 82 működő céget és mintegy 42 tulajdonost említett a vezetőség).

Létrehozataluk óta az ipari parkok területe számottevően növekedett, közműveik kiépítettsége, ingatlan- és szolgáltatáskínálatuk fejlődött (4. táblázat).

Az ipari parkokban müködő, legalább 20 föt foglalkoztató cégek között nagy különbségek vannak (5. táblázat, 4 . ábra). Gazdasági potenciálját tekintve kiemelkedik a Debreceni Regionális Innovációs Tudományos és Technológiai 
4. táblázat: A debreceni ipari parkok infrastruktúrája és szolgáltatásai Infrastructure and services provided by industrial parks in Debrecen

\begin{tabular}{|c|c|c|}
\hline & Infrastruktúra & \\
\hline $\begin{array}{l}\text { Debreceni Regioná- } \\
\text { lis Innovációs Tu- } \\
\text { dományos és Tech- } \\
\text { nológiai Park (Ha- } \\
\text { tár út) }\end{array}$ & $\begin{array}{l}\text { Közművek: úthálózat, ivóvíz- és csator- } \\
\text { nahálózat, elektromos- és gázhálózat, } \\
\text { telefon- és internethálózat, közvilágítás; } \\
\text { bérelhető ingatlanok: üzem- és raktár- } \\
\text { csarnokok, inkubátorház, szolgáltató- } \\
\text { központ; közösségi közlekedés, személy- } \\
\text { gépkocsi-parkoló }\end{array}$ & $\begin{array}{l}\text { Őrzés-védelem, étkeztetés, irodai és } \\
\text { logisztikai szolgáltatások, konferen- } \\
\text { ciaterem és tárgyalók, vendégszobák, } \\
\text { posta, hulladékgyüjtés, takarítás, ta- } \\
\text { nácsadás (különböző területek), } \\
\text { üzemorvos, parkgondozás. }\end{array}$ \\
\hline $\begin{array}{l}\text { Debreceni Regioná- } \\
\text { lis Innovációs Tu- } \\
\text { dományos és Tech- } \\
\text { nológiai Park } \\
\text { (Trimodális Logisz- } \\
\text { tikai Központ) }\end{array}$ & $\begin{array}{l}\text { Közművek: úthálózat, ivóvíz- és csator- } \\
\text { nahálózat, elektromos- és gázhálózat, } \\
\text { telefon- és internethálózat, közvilágítás; } \\
\text { bérelhető ingatlanok: üzem- és raktár- } \\
\text { csarnokok, személygépkocsi-parkoló }\end{array}$ & $\begin{array}{l}\text { Őrzés-védelem, étkeztetés, irodai és } \\
\text { logisztikai szolgáltatások, posta, hul- } \\
\text { ladékgyüjtés, takarítás, tanácsadás } \\
\text { (különböző területek), parkgondozás }\end{array}$ \\
\hline $\begin{array}{l}\text { Debreceni Egyetem } \\
\text { Tudományos, Tech- } \\
\text { nológiai és Innová- } \\
\text { ciós Park }\end{array}$ & $\begin{array}{l}\text { Közművek: úthálózat, ivóvíz-, csapadék- } \\
\text { víz- és szennyvízhálózat, elektromos és } \\
\text { gázhálózat, telefon- és internethálózat, } \\
\text { közvilágítás; közösségi közlekedés }\end{array}$ & $\begin{array}{l}\text { Őrzés-védelem, hulladékgyűjtés, ta- } \\
\text { karítás, parkgondozás, alapszintű } \\
\text { irodai kiegészítő szolgáltatások, mar- } \\
\text { keting, gazdasági, informatikai, hu- } \\
\text { mánerőforrás-fejlesztést segítő szol- } \\
\text { gáltatások, fordítás, tolmácsolás, K+F, } \\
\text { innovációs szolgáltatások }\end{array}$ \\
\hline $\begin{array}{l}\text { Logisztikai Szolgál- } \\
\text { tató Központ és } \\
\text { Ipari Park }\end{array}$ & $\begin{array}{l}\text { Közművek: úthálózat, ivóvíz-, csapadék- } \\
\text { víz- és szennyvízhálózat, elektromos és } \\
\text { gázhálózat, telefon- és internethálózat, } \\
\text { közvilágítás; bérelhető ingatlanok: rak- } \\
\text { tárak; közösségi közlekedés, iparvágány, } \\
\text { személygépkocsi- és haszongépjármű- } \\
\text { parkoló }\end{array}$ & $\begin{array}{l}\text { Őrzés-védelem, helyi tűzoltóság, } \\
\text { komplex logisztikai szolgáltatások, } \\
\text { háttérirodai szolgáltatások }\end{array}$ \\
\hline $\begin{array}{l}\text { Debreceni Nyugati } \\
\text { Ipari Park }\end{array}$ & $\begin{array}{l}\text { Közművek: úthálózat, ivóvíz- és csator- } \\
\text { nahálózat, elektromos és gázhálózat, te- } \\
\text { lefon- és internethálózat, közvilágítás; } \\
\text { bérelhető ingatlanok: irodák, raktár- és } \\
\text { üzemcsarnokok; közösségi közlekedés, } \\
\text { iparvágány, személygépkocsi- és ha- } \\
\text { szongépjármű-parkoló }\end{array}$ & $\begin{array}{l}\text { Őrzés-védelem, étkeztetés, takarítás, } \\
\text { hulladékgyüjtés, karbantartás, irodai } \\
\text { és logisztikai szolgáltatások, posta, } \\
\text { tanácsadás (különböző területek), } \\
\text { üzemorvos, gépkölcsönzés }\end{array}$ \\
\hline
\end{tabular}

Forrás: saját adatgyüjtés a működtető cégek honlapja alapján.

Park Határ úton elhelyezkedő egysége, mely elsősorban 130 hektáros kiterjedésének köszönheti kiemelkedő szerepét. Ebben az ipari parkban mintegy 50 cég 5000 alkalmazottját foglalkoztatják. Ez az egyetlen ipari profilú park, ahol a fémfeldolgozás és gépipar (pl. FAG Magyarország Kft.), illetve az elektronikai ipar (pl. National Instruments Europe Kft.) dominál, és itt található a Richter 
5. táblázat: Az ipari park címmel rendelkező objektumokban működő, 20 főnél többet foglalkoztató cégek legfontosabb jellemzői Debrecenben (2018. május)

Characteristics of companies located in government-approved industrial parks in Debrecen with more than 20 employees (May 2018)

\begin{tabular}{lcc}
\hline \multicolumn{1}{c}{ Objektum } & $\begin{array}{c}\text { Cégek száma } \\
(\mathrm{db})\end{array}$ & $\begin{array}{c}\text { Foglalkoztatottak száma } \\
\left(f^{\prime \prime}\right)\end{array}$ \\
\hline $\begin{array}{l}\text { Debreceni Regionális Innovációs Tudományos és Techno- } \\
\text { lógiai Park }\end{array}$ & $\begin{array}{c}23 \\
\left(19^{*}+4^{* *}\right)\end{array}$ & $\begin{array}{c}4951 \\
\left(4789^{*}+126^{* *}\right)\end{array}$ \\
\hline $\begin{array}{l}\text { Debreceni Egyetem Tudományos, Technológiai és Inno- } \\
\text { vációs Park }\end{array}$ & 1 & 1400 \\
\hline Logisztikai Szolgáltató Központ és Ipari Park & 5 & 1011 \\
\hline Debreceni Nyugati Ipari Park & 12 & 784 \\
\hline Összesen & 41 & 8146 \\
\hline
\end{tabular}

* Határ út, ${ }^{* *}$ Trimodális Logisztikai Központ.

Forrás: saját gyüjtés és a Creditreform Céginformáció adatai alapján.

Gedeon Nyrt. debreceni üzeme is. A DRITTP repülőtér szomszédságában működő másik egysége a Trimodális Logisztikai Központ, amelynek tevékenységi köre kevésbé differenciált, elsősorban szállítással és raktározással foglalkozó cégeknek biztosít telephelyeket.

4. ábra: A legalább 20 fót foglalkoztató vállalkozások alkalmazásban állóinak gazdasági ágazatok szerinti megoszlás az ipari parkokban Workforces of companies in industrial parks with more than 20 employees (by economic sectors)

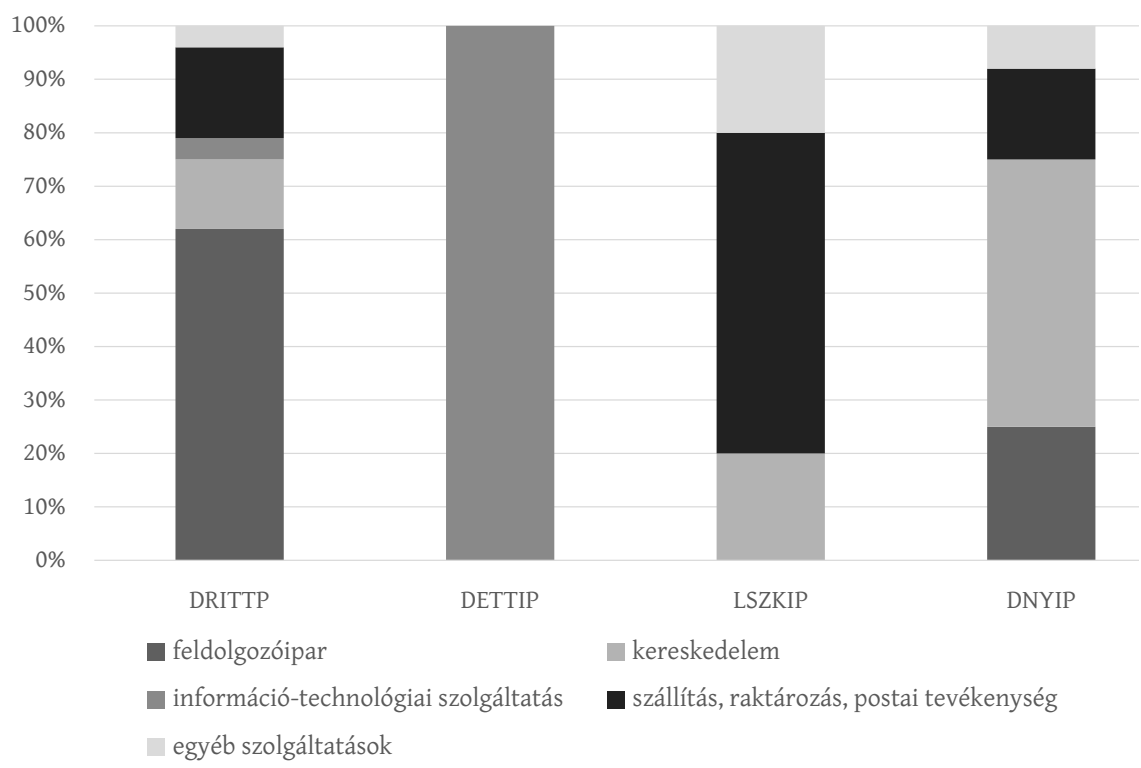

Forrás: saját gyüjtés és a Creditreform Céginformáció adatai alapján. 
2018-ban a Debreceni Egyetem Tudományos Technológiai és Innovációs Ipari Parkban mindössze egy vállalat működött: a megosztott szolgáltatóközpontok legnagyobb reprezentánsa, az IT Services Hungary Kft., amely mintegy 1400 föt foglalkoztatott. 2019-ben ide települt a Thyssenkrupp autóalkatrészgyártó üzeme, ezzel oldódott az ipari parki vállalatok egyoldalú gazdasági tevékenysége.

Meg kell jegyezni, hogy e tudományos és technológiai parkokban csak korlátozottan foglalkoznak K+F-tevékenységgel, és alig figyelhető meg a Debreceni Egyetemen keletkezett innovációk gyakorlati alkalmazása. A DRITTP esetében kivételt jelent a Richter Gedeon Nyrt. gyógyszerkísérleteket is folytató biotechnológiai üzeme, valamint a National Instruments Europe Kft. keretein belül folyó gyártmányfejlesztés. Az ipari parkban a felsőoktatási intézménnyel kialakított kapcsolatok elsősorban a cégek számára szükséges munkaerő-utánpótlás biztosítására korlátozódnak: gyakorlatorientált duális képzéseket indítanak (pl. FAG Magyarország Kft., National Instruments Europe Kft.) és e vállalatok kihelyezett egyetemi tanszékeket működtetnek (pl. National Instruments Europe Kft. - Elektrotechnikai Gyártás- és Méréstechnikai Kihelyezett Tanszék). A DETTIP jelenlegi két vállalatának egyetemmel fennálló kapcsolatai csak a munkaerő képzésére korlátozódnak. A következő években előrelépés várható: a tervek szerint itt épül fel a Debreceni Egyetem „innovációs plázája”, Járműipari Kutatási-Fejlesztési Intézete, valamint egy új oltóanyaggyár. Bővül tehát az ipari park profilja és erősödhet kapcsolata az egyetemmel.

Közel 10 vállalkozással, köztük 5 jelentős foglalkoztatóval - és együttesen mintegy 1000 alkalmazásban állóval - jelenik meg a döntően szállítással, raktározással foglalkozó cégeket tömörítő Logisztikai Szolgáltató Központ és Ipari Park. A Debreceni Nyugati Ipari Park mikro-, kis-, és középvállalkozásai miatt emelhető ki: az egykori házgyár szétaprózott ingatlanjaiban mintegy 70-80 cég müködik, a helyben legalább 20 föt foglalkoztató cégek közel 800 munkahelyet jelentenek. Az ipari park fő profilja a kereskedelem, mely némi iparral és logisztikai tevékenységekkel egészül ki.

Ha figyelembe vesszük, hogy a helyben foglalkoztatottak száma a 2011. évi népszámlálás alapján mintegy 96 ezer fó körül alakult Debrecenben, akkor a mintegy 8-9 ezer ipari parkokban alkalmazásban álló minden bizonnyal 10\% alatti súlyt képvisel a mai helyi gazdaságban. Árnyaltabb képet kapunk, ha a vállalkozásokra szükítjük vizsgálatainkat. Az ipari parkokban müködő helyi székhelyű vállalkozások a debreceni cégeknek megközelítőleg 9\%-át teszik ki (6. táblázat), azonban a nagyobb vállalkozások (500föt meghaladók) részaránya nagyobb, 25\% körüli. Ezek a nagyobb vállalatok ugyanis már az új évezredben jelentek meg többnyire Debrecenben, igényeik kielégítése (pl. megfelelő nagyságú telek, magas színvonalú infrastruktúra) csak az újonnan kialakított ipari parkokban volt lehetséges.

A jelentős részben ipari parkokban megvalósuló külföldi működőtőke-befektetések fontos alakítói a város ezredforduló utáni fejlődési pályájának. Az el- 
6. táblázat: Az ipari park címmel rendelkező objektumokban működő, 20 főnél többet foglalkoztató helyi székhelyủ cégek aránya vállalati nagyságrend szerint (2018) Proportion of locally headquartered companies with more than 20 employees operating in government-approved industrial parks by company size (2018)

\begin{tabular}{lccc}
\hline Nagyságkategóriák & $\begin{array}{c}\text { Az ipari parkokban müködö helyi } \\
\text { székhelyü cégek száma }(d b)\end{array}$ & $\begin{array}{c}\text { Az összes debreceni szék- } \\
\text { helyü cég }(d b)\end{array}$ & $\begin{array}{c}\text { Az ipari parki cégek } \\
\text { aránya }(\%)\end{array}$ \\
\hline 20-49 fö & 13 & 244 & 5,3 \\
$50-249$ fó & 15 & 116 & 12,9 \\
$250-499$ fó & 3 & 14 & 21,4 \\
500 fo felett & 3 & 11 & 27,3 \\
\hline Összesen & 34 & 385 & 8,9 \\
\hline
\end{tabular}

Megjegyzés: Az 5. táblázat adataitól való eltérés azzal magyarázható, hogy a városi adatokkal történő összehasonlíthatóság kedvéért csak a helyi székhelyü cégeket vettük figyelembe, és így bizonyos vállalatok (pl. IT Services Hungary $\mathrm{Kft}$.) kiestek a vizsgálati körböl.

Forrás: saját gyüjtés és a Creditreform Céginformáció adatai alapján.

ső ipari parki fejlesztéseket követő betelepülők megerősítették az exportorientált, nagyvállalati és iparhoz kötődő szegmenst Debrecen gazdaságában (szer-

5. ábra: Debrecen viszonylagos gazdasági pozíciójának változása a nagyvárosok mezőnyében The relative position of the Debrecen economy among the Hungarian larger cities

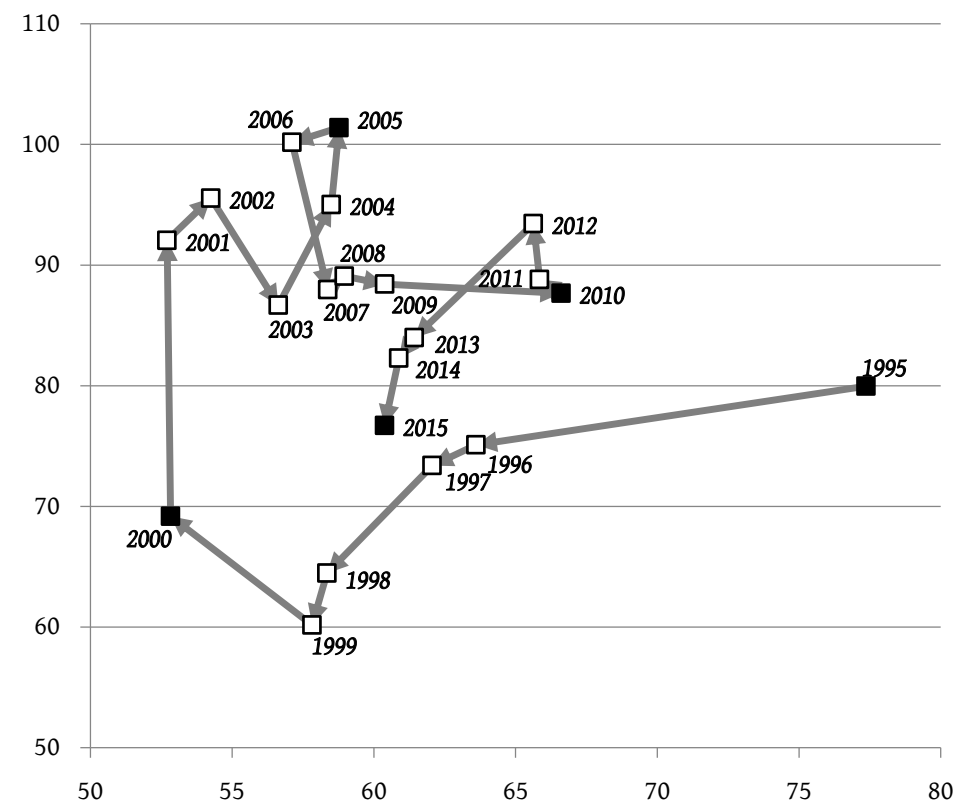

Függóleges tengely: egy lakosra jutó bruttó hozzáadott érték a csoportátlag (Debrecen, Györ, Kecskemét, Miskolc, Nyirregyháza, Pécs, Szeged, Székesfehérvár) százalékában; vízszintes tengely: komplex szerkezeti mutató az export aránya, a vállalatok átlagos mérete és az ipari társas vállalkozások aránya alapján: balról jobbra növekszik az export és az ipari társas vállalkozások aránya, illetve növekszik az átlagos vállalatméret a csoportátlag százalékában. Forrás: a KSH és a NAV adatai alapján. 
kezeti hatás), másrészt hozzájárultak a város (egy lakosra vetített) gazdasági teljesítményének jelentős emelkedéséhez (növekedési hatás). A felfutó cégeknek komoly szerepe van abban, hogy a nagyvárosok között csak mérsékelt dinamikát felmutató, jó esetben is a középmezőnybe sorolható Debrecen vállalkozásainak egy lakosra jutó összesített bruttó hozzáadott értéke a magyarországi nagyvárosi átlaghoz képest nem romlott tovább, sőt, 2005-ben és 2006-ban a csoportátlag fölé került (5. ábra). A külső szereplők Debrecenbe vonzása és így a gazdaság méreteinek növelése mellett a helyben múködő és újonnan alapított vállalkozások területi „újraelosztásában” is jelentős szerepük van az ipari parkoknak (területi hatás): a város belső és délkeleti részein elhelyezkedő, a vasút mellett kialakult örökölt iparforgalmi övezetekkel szemben az autópálya és repülőtér közelében fekvő nyugati peremterületek súlyát növelik.

Az ipari parkok várhatóan a jövőben is jelentős szerepet töltenek be a város gazdasági életében. A 2016-2018 között Debrecenben bejelentett nagyobb volumenű munkahelyteremtő beruházások egy részét (a foglalkoztatottak szá-

7. táblázat: Legalább 100 fős többletfoglalkoztatást eredményező, 2016-2018 között bejelentett új beruházások és ipari parki telepítésük

Investments announced 2016-2018 resulting in additional employment of at least 100 persons (with respective industrial park)

\begin{tabular}{|c|c|c|c|}
\hline A cég neve & $\begin{array}{c}\text { Új munkahelyek } \\
\text { száma (db) }\end{array}$ & Tevékenység & Helyszín \\
\hline BMW & 1000 & Járműipar: új üzem & Északnyugati Gazdasági Övezet \\
\hline FAG Magyarország & 510 & Gépipar: kapacitásbővítés & DRITTP (Határ út) \\
\hline Krones & 500 & $\begin{array}{l}\text { Élelmiszeripari gépgyártás: } \\
\text { új üzem }\end{array}$ & Déli Ipari Park \\
\hline Continental & 450 & Járműipar: új üzem & Déli Ipari Park \\
\hline Flowserve & 400 & SSC: új központ & $\begin{array}{l}\text { Lion Office Center (később } \\
\text { Agora Office Debrecen) }\end{array}$ \\
\hline Thyssenkrupp & 250 & Járműipar: új üzem & DETTIP \\
\hline $\begin{array}{l}\text { National Instru- } \\
\text { ments }\end{array}$ & 210 & $\begin{array}{l}\text { Elektronika: } \mathrm{K}+\mathrm{F} \text {, globális } \\
\text { szolgáltatás bővítése }\end{array}$ & DRITTP (Határ út) \\
\hline EPAM & 200 & SSC: kapacitásbővítés & $\begin{array}{l}\text { Belváros (később Forest Office } \\
\text { Debrecen) }\end{array}$ \\
\hline Transcosmos & 150 & SSC: kapacitásbővítés & DRITTP (Határ út) \\
\hline Diehl Aircabin & 150 & SSC: új központ & Forest Office Debrecen \\
\hline Richter Gedeon & 125 & $\begin{array}{l}\text { Gyógyszeripar: kapacitás- } \\
\text { bővítés }\end{array}$ & DRITTP (Határ út) \\
\hline Intertanker & 120 & Járműipar: új üzem & DRITTP (Határ út) \\
\hline Alföldi Tej & 110 & $\begin{array}{l}\text { Élelmiszeripar: kapacitás- } \\
\text { bővítés }\end{array}$ & Köntösgát utca \\
\hline British Telecom & 100 & SSC: kapacitásbővítés & Belváros \\
\hline IT Services & 100 & SSC: kapacitásbővítés & Lion Office Center \\
\hline
\end{tabular}

Forrás: EDC Debrecen adatszolgáltatása. 
mát tekintve körülbelül harmadát) ipari parkokban tervezik letelepíteni (7. táblázat). A legnagyobb, várhatóan 600-1000fó számára munkahelyet teremtő BMW-beruházás - óriási területigénye folytán - ugyanakkor nem a jelenlegi ipari parkok valamelyikében, hanem a kiépítés alatt álló Északnyugati Gazdasági Övezetben valósul meg.

\section{Összefoglalás}

Az ipari parkok Debrecen gazdaságfejlesztési terveinek fontos részei, a település fejlődésének „zászlóshajóiként” tekintenek rájuk. Az ipari parkok fejlesztése, területük növelése és szolgáltatásaik bővítése, valamint a megközelíthetőségük javítása a feladat. Az ipari parkok hozzájárulnak a város gazdasági versenyképességének erősítéséhez: a város délkeleti részén elhelyezkedő régi iparterületekkel szemben az autópálya és repülőtér közelében fekvő nyugati peremterületek súlyát növelik.

Több új ipari parkot hoztak létre az elmúlt évtizedekben: a Debreceni Egyetem Tudományos és Technológiai Innovációs Parkot, a Debreceni Regionális Innovációs és Tudományos Technológiai Parkot, valamint az egykori ipari területekhez kapcsolódó Debreceni Nyugati Ipari Parkot. A logisztikai központokból kialakult ipari parkok csoportjába tartozik a Logisztikai Szolgáltató Központ és Ipari Park, míg a Debreceni Regionális Innovációs és Tudományos Technológiai Park repülőtéren kialakított része (Trimodális Logisztikai Központ) egy korábbi katonai területen jött létre, melyhez jelentős zöldmezős területeket csatoltak. Az ipari parkokba települt vállalatok ágazati specializációja csak néhány esetben alakult ki: a Debreceni Regionális Innovációs és Tudományos Technológiai Park inkább feldolgozóipari irányultságú, a Debreceni Nyugati Ipari Parkban a kereskedelemmel foglalkozó vállalatok vannak túlsúlyban, míg a Logisztikai Szolgáltató Központ és Ipari Park, valamint a Debreceni Regionális Innovációs és Tudományos Technológiai Park repülőtéren kialakított része esetében a szállítás-raktározás ágazat dominál. A négy ipari park közül kettő rendelkezik tudományos és technológiai park minősítéssel, ahol egyelőre azonban alig folyik K+F-tevékenység, a Debreceni Egyetemmel kialakított együttműködésük elsősorban a letelepült vállalkozások számára szükséges munkaerő képzésére korlátozódik.

Az ipari parkokban működő vállalatok fontos szereplői a város gazdasági életének (ez különösen igaz a nagyobb létszámot foglalkoztató cégekre), és ez a helyzet (figyelembe véve a már bejelentett bővítési szándékokat is) a következő 4-5 évben valószínűleg megmarad. A városi önkormányzat támogatása elsősorban két területen jelentkezik: közlekedési beruházások segítségével javítják az ipari parkok megközelíthetőségét, valamint a szabályozási előírások megváltoztatásával támogatják területük bővítését. A távolabbi jövőt illetően a Déli 
Ipari Park helyzete, illetve a BMW-beruházást kísérő fejlesztések kerültek a figyelem középpontjába. Előbbi esetben a fő kérdés az, hogy szükségesnek látja-e a város az ipari park cím elérését (a jelenlegi viszonyokat és a jogszabályi feltételeket tekintve 3-4 év múlva lesz a pályázatra reális lehetőség), míg a BMW esetében szóba került egy mintegy 100 hektáros terület kialakítása az üzemtől északra. Az ipari parki fejlesztések Debrecen gazdaságának hosszabb távú térszerkezeti átrendeződését vetítik előre, főleg a város nyugati és déli pereme felé.

\section{Köszönetnyilvánítás}

A mű a KÖFOP-2.1.2-VEKOP-15-2016-00001 azonosítószámú, „A jó kormányzást megalapozó közszolgálat-fejlesztés" elnevezésű kiemelt projekt keretében, a Nemzeti Közszolgálati Egyetem felkérésére készült.

\section{Irodalom}

Albahari, A., Barge-Gil, A., Pérez-Canto, S., Modrego, A. (2018): The influence of Science and Technology Park characteristics on firms' innovation results. Papers in Regional Science, 2., 253-279. http://doi.org/gdrxfp

Annerstedt, J. (2006): Science parks and high-tech clustering. In: Bianchi, P., Labory, S. (eds.): International handbook on industrial policy. Edward Elgar, Cheltenham, Northampton, 279-297. http://doi.org/c84n

Barta Gy. (2002): Tudományos parkok: intézményesült tudásközösségek a térségfejlesztésben. In: Buzás N., Lengyel I. (szerk.): Ipari parkok fejlődési lehetőségei: regionális gazdaságfejlesztés, innovációs folyamatok és klaszterek. JATEPress, Szeged, 109-124.

Benko, G. (1992): Technológiai parkok és technopoliszok földrajza. MTA RKK, Budapest

Colombo, M. G., Delmastro, M. (2002): How effective are technology incubators? Evidence from Italy. Research Policy, 7., 1103-1122. http://doi.org/dn8ctw

Díez-Vial, I., Fernández-Olmos, M. (2017): The effect of science and technology parks on a firm's performance: a dynamic approach over time. Journal of Evolutionary Economics, 3., 413-434. http://doi.org/gbf8vd

Díez-Vial, I., Montoro-Sánchez, Á. (2016): How knowledge links with universities may foster innovation: The case of a science park. Technovation, 50-51., 41-52. http://doi.org/c84p

Dusek T., Lukovics M. (2014): Az ELI és az ELI Science Park gazdasági hatásvizsgálata. Területi Statisztika, 3., 202-219.

EDC (2015): Why in Debrecen - Economy, Investment, Innovation, 2015. Debrecen

Excellence (2003): Debrecen Megyei Jogú Város Operatív Fejlesztésének Programja. Budapest, Debrecen

Euro-Régió Ház (2006): Debrecen Megyei Jogú Város 2007-2013 közötti fejlesztésének stratégiai és operatív programja. Debrecen

Euro-Régió Ház (2007): Debrecen Megyei Jogú Város Integrált Városfejlesztési Stratégiája. Debrecen

Euro-Régió Ház, INNOVA (2014): Debrecen Megyei Jogú Város Településfejlesztési Koncepciója 2014-2020. Debrecen

Faragó L., Lux G. (2014): Kurrens portéka vagy múzeumi tárgy? Növekedési pólusok és iparági körzetek a fejlesztéspolitikában. Tér és Társadalom, 2., 11-30. http://doi.org/cwxs 
Grasselli G. (1996): Az ipari park, mint a régió fejlesztésének lehetséges alternatívája. Comitatus, 6., 3-19.

Guadix, J., Carrillo-Castrillo, J., Onieva, L., Navascues, J. (2016): Success variables in science and technology parks. Journal of Business Research, 11., 4870-4875. http://doi.org/gd2wc8

Haselmayer, S. (2004): Why science and technology parks go urban: towards embedded innovation environments. Urbanistica Informazioni, 2., 35-46.

Hobbs, K. G., Link, A. N., Scott, J. T. (2017): The growth of US science and technology parks: does proximity to a university matter?. The Annals of Regional Science, 2., 495-511. http://doi.org/c84q

Józsa V. (2019): A vállalati beágyazódás útjai Magyarországon. Dialóg Campus Kiadó, Budapest

Kiss É. (2001): A hazai ipari parkok néhány jellemző vonása. Falu Város Régió, 9., 17-22.

Kiss É. (2013): Sokszínú ipari parkállomány. In: Kiss É. (szerk.): A hazai ipari parkok különböző dimenzióban. Dialóg Campus Kiadó, Budapest, Pécs, 11-39.

Kiss É., Tiner T. (2012): Depending on motorways - transport connections of Hungarian industrial parks and their enterprises. Hungarian Geographical Bulletin, 2., 131-153.

Kozma G. (2002): Terület- és településmarketing. Kossuth Egyetemi Kiadó, Debrecen

Kőszegfalvi Gy. (1978): A korszerü ipartelepités alapjai. Műszaki Könyvkiadó, Budapest

Kullmann Á. (2000): A magyarországi ipari parkok fejlődési pályái. Tér és Társadalom, 2-3., 63-72. http://doi.org/c84r

Lamperti, F., Mavilia, R., Castellini, S. (2017): The role of science parks: a puzzle of growth, innovation and R\&D investments. The Journal of Technology Transfer, 1., 158-183. http://doi.org/f9psm8

Lengyel I., Imreh Sz., Kosztopulosz A. (2002): Az ipari park fogalomköre és kategóriái. In: Buzás N., Lengyel I. (szerk.): Ipari parkok fejlődési lehetőségei: regionális gazdaságfejlesztés, innovációs folyamatokés klaszterek. JATEPress, Szeged, 55-76.

Liberati, D., Marinucci, M., Tanzi, G. M. (2016): Science and technology parks in Italy: main features and analysis of their effects on the firms hosted. The Journal of Technology Transfer, 4., 694-729. http://doi.org/f8vcfm

Lőcsei H., Nemes Nagy J. (2003): A Balatoni régió gazdasági súlya és belső térszerkezete. In: Nemes Nagy J. (szerk.): Kistérségi mozaik. ELTE Regionális Földrajzi Tanszék, MTA-ELTE Regionális Tudományi Kutatócsoport, Budapest, 134-149. (Regionális Tudományi Tanulmányok; 8.)

Löfsten, H., Lindelöf, P. (2002): Science parks and the growth of new technology-based firms - academicindustry links, innovation and markets. Research Policy, 6., 859-876. http://doi.org/b373wc

Lukács A. (2013): Az ipari parkok a feldolgozóipar klaszterizációjában, koncentrációjában és specializációjában a 21. század elején. In: Kiss É. (szerk.): A hazai ipari parkok különböző dimenzióban. Dialóg Campus Kiadó, Budapest, Pécs, 236-256.

Lux G. (2013): Az ipari parkok a területi versenyképességben: telephelyek vagy fejlesztési csomópontok? In: Kiss É. (szerk.): A hazai ipari parkok különböző dimenzióban. Dialóg Campus Kiadó, Budapest, Pécs, 294-309.

Molnár E. (2013a): A közlekedési adottságok szerepe a Hajdú-Bihar megyei ipari parkok fejlődésében. In: Kiss É. (szerk.): A hazai ipari parkok különböző dimenzióban. Dialóg Campus Kiadó, Budapest, Pécs, 144-161.

Molnár E. (2013b): Az autóipar mint húzóágazat az ipari parkokban: telephelyválasztás, közlekedési adottságok. In: Kiss É. (szerk.): A hazai ipari parkok különböző dimenzióban. Dialóg Campus Kiadó, Budapest, Pécs, 210-235.

Molnár E., Dézsi Gy., Lengyel I. M., Kozma G. (2018): Vidéki nagyvárosaink gazdaságának összehasonlító elemzése. Területi Statisztika, 6., 610-637. http://doi.org/c84s

Nikodémus A. (2002): Az ipari parkok szerepe a kormány befektetés-politikájában. In: Buzás N., Lengyel I. (szerk.): Ipari parkok fejlődési lehetőségei: regionális gazdaságfejlesztés, innovációs folyamatok és klaszterek. JATEPress, Szeged, 7-23.

Pál Á., Zsigó L. (1981): Az előkészített ipartelepítés példái az Alföldön. Alföldi Tanulmányok, 5., 113-130.

Pénzes J. (2014): Periférikus térségek lehatárolása. Dilemmák és lehetőségek. Didakt Kiadó, Debrecen

Rakusz L. (2000): Ipari parkok, 1994-2000. Ipari Parkok Egyesülete, Budapest

Ramírez-Alesón, M., Fernández-Olmos, M. (2018): Unravelling the effects of science parks on the innovation performance of NTBFs. The Journal of Technology Transfer, 2., 482-505. http://doi.org/gc8mk5 
Rechnitzer J. (2002): Az ipari park mint a regionális politika eszköze. In: Buzás N., Lengyel I. (szerk.): Ipari parkok fejlődési lehetőségei: regionális gazdaságfejlesztés, innovációs folyamatok és klaszterek. JATEPress, Szeged, 77-92.

Squicciarini, M. (2009): Science parks: Seedbeds of innovation? A duration analysis of firms's patenting activity. Small Business Economics, 2., 169-190. http://doi.org/dp4mt3

Syed, H., Klaiber, H. A., Sheldon, I. (2018): The impact of science parks on small-and medium-sized enterprises' productivity distributions: the case of Taiwan and South Korea. Small Business Economics, 1-19. http://doi.org/c84t

Tájékoztató a Magyarországon müködő ipari parkok helyzetéról. Budapest, 2016 október. http://www.kormany.hu/download/4/fb/f0000/Tájékoztató\%20a\%20Magyarországon\%20müködő\%20ipari\%20parkok\%20helyzetéről\%20a\%202016-os\%20beszámolók\%20alapján.pdf\#!DocumentBrowse (Letöltés: 2019. január 5.)

Vásquez-Urriago, Á. R., Barge-Gil, A., Rico, A. M. (2016): Science and technology parks and cooperation for innovation: Empirical evidence from Spain. Research Policy, 1., 137-147. http://doi.org/c84v

VÁTI, Excellence (2000): Debrecen Megyei Jogú Város Gazdaságfejlesztési Koncepciója. Budapest, Debrecen 